\title{
Effect of maturity stage of Italian rye grass and lucerne on ruminal nitrogen degradability
}

\author{
R Amrane, B Michalet-Doreau * \\ INRA, Station de Recherches sur la Nutrition des Herbivores, Theix, 63122, \\ Saint-Genès-Champanelle, France
}

(Reçu le15 Septembre 1992; accepté le 6 July 1992)

\begin{abstract}
Summary - Ruminal $\mathrm{N}$ degradability of Italian rye grass and luceme was studied using the nylon bag technique: 5 samples of rye grass and 5 of lucerne were harvested during the 1st cycle of growth at different stages of maturity, between the leafy stage and the end of heading for rye grass and between the vegetative stage and the end of budding for lucerne. For grass, degradability values were high at the beginning of growth, with a mean of $72.2 \%$ in the period from leafy stage to heading, but they decreased rapidly after this stage to $64.6 \%$ (of $1.1 \% / d$ ). For lucerne, the decrease in $\mathrm{N}$ degradability was approximately linear between the vegetative stage $(79.0 \%)$ and the end of budding $(70.0 \%)$, a decrease of $0.3 \% / \mathrm{d}$. After correction to take into account microbial contamination of bag residues, the reduction of $\mathrm{N}$ degradability with stage of maturity appears smaller, ie $5 \%$ for rye grass and $4 \%$ for lucerne.
\end{abstract}

in situ degradability / nitrogen / fresh forage / maturity stage

Résumé - Influence du stade de végétation sur la dégradabilité in situ de l'azote dans le rumen d'un ray-grass Italien et d'une luzerne. La dégradabilité de l'azote dans le rumen de 2 fourrages était étudiée en utilisant la technique des sachets de nylon : un ray-grass Italien et une luzeme en étaient récoltés respectivement à 5 stades de maturité différents, du stade feuillu au stade fin de l'épiaison pour le ray-grass et du stade végétatif à la fin du bourgeonnement pour la luzeme. La dégradabilité de l'azote du ray-grass était élevée en début de végétation, soit en moyenne $72,2 \%$ entre le stade feuillu et l'épiaison, puis elle diminuait rapidement après l'épiaison à $64,6 \%$ (soit 1,1\% (j). La dégradabilité de l'azote de lá luzerne diminuait de façon presque linéaire entre les stades végétatif $(79,0 \%)$ et fin du bourgeonnement $(70,0 \%)$, soit une diminution de $0,3 \% / j$. Après correction pour prendre en compte la contamination microbienne des résidus de sachets, la diminution de la dégradabilité de l'azote avec l'âge du fourrage est plus faible, soit $5 \%$ pour le ray-grass et $4 \%$ pour la luzeme.

dégradabilité in situ / azote / fourrage vert / stade de végétation /

\footnotetext{
* Correspondence and reprints
} 


\section{INTRODUCTION}

Most methods used to measure the nitrogen $(\mathrm{N})$ values in ruminant feeds are based on estimation of the quantity of amino acids that can be absorbed by the small intestine. These amino acids have 2 possible origins: dietary or microbial. The feed $\mathrm{N}$ which escapes rumen degradation is one of the major elements in the determination of feed $\mathrm{N}$ value. In vivo measurement of dietary $\mathrm{N}$ degradation in the rumen is laborious and alternative methods microbiological, chemical and enzymatic have been sought (Lindberg, 1985; Nocek, 1988). Among these different methods, the nylon bag technique is the most commonly used (Madsen and Hvelplund, 1985; Nocek, 1988). This technique allows the description of the kinetics of dietary $\mathrm{N}$ degradation in the rumen (Orskov and McDonald, 1979). The extent of dietary N degradation in the rumen is determined by the rate of degradation of feed $\mathrm{N}$ and the rumen outflow rate of undigested $N$ (Orskov and Mc Donald, 1979).

A considerable amount of data is available on $\mathrm{N}$ degradability of concentrates (Madsen and Hvelplund, 1985; Demarquilly et al, 1989; Tamminga et al, 1990). Recently, studies on fresh forages have increased, especially concerning variations of $\mathbf{N}$ degradability according to stage of maturity, but the results are incomplete (Van Eys and Reid, 1987), or it is difficult to compare them. Some trials do not take into account the microbial contamination of residues (Le Goffe, 1988; Van Vuuren et al, 1990). Omitting microbial contamination results in an overestimation of the decreasing effect of maturation on ruminal protein degradability. In other studies, only 2 stages of maturity are studied (MichaletDoreau, 1990; Vik-Mo, 1989), and it is not possible to describe the changes in $\mathrm{N}$ degradability with stage of maturity.
Therefore, in this study, the variations in in situ $\mathrm{N}$ degradability of 2 forages have been examined during the first growth cycle, the results being corrected or not, taking into account the microbial contamination.

\section{MATERIALS AND METHODS}

\section{Forages}

The forages were grown at the Forage Research Station at Oued Smar in Algeria. The climate is subhumid with mild winters and hot summers. Average rainfall is $672 \mathrm{~mm}$ per yr. Rye grass received nitrogen fertilization, $60 \mathrm{~kg} \mathrm{~N} \mathrm{ha}^{-1}$, before first cutting. The samples of the same forage originated from the same plot.

Five samples of Italian rye glass (Lolium multiflorum) and 5 samples of lucerne (Medicago sativa) were cut during the first growth cycle at different stages of maturity between March 7 May 2, 1990. The first sample corresponded to the leafy vegetative stage for rye grass and lucerne respectively, and the last to the end of heading and budding. Moving height was $\approx 6 \mathrm{~cm}$; then samples were dried at $60^{\circ} \mathrm{C}$ for $48 \mathrm{~h}$ and ground through a $0.8 \mathrm{~mm}$ screen.

\section{In situ measurements}

In situ measurements of rumen degradation was carried out using 3 dry Holstein cows fitted with a rumen cannula. They received $7 \mathrm{~kg} D M$ grass hay and concentrate (70/30) per animal per day, divided over 2 equal meals given at 8 and $17 \mathrm{~h}$. The chemical composition of the concentrate has been described by Cerneau and MichaletDoreau (1991). After 3 wk adaptation of animals to the diet, nylon bags (internal dimensions: $6 x$ $11 \mathrm{~cm}$, pore size $46 \mu \mathrm{m}$ ), containing $3 \mathrm{~g}$ of forages, were all placed in the rumen at the same time, before the first meal of the day, and the removed after $2,4,7,17,24$ or $48 \mathrm{~h}$ of incubation. After incubation, the bags were washed in cold water for $6 \mathrm{~min}$ ( 3 successive baths of $2 \mathrm{~min}$ ), then dried in a forced air oven at $80^{\circ} \mathrm{C}$ for $48 \mathrm{~h}$. There were 6 measurements for each point in time ( 3 cows $\times 2$ replications). 


\section{Chemical analysis}

The nitrogen content of the forages and of the bag residues after incubation was determined by the Kjeldahi method, and the cell wall constituents (NDF, ADF, ADL) were determined in the forages (Goering and Van Soest, 1970).

\section{Calculations}

Nitrogen disappearance in the rumen was adjusted to an exponential model (Orskov and McDonald, 1970),

$$
\% \mathrm{~N} \text { degraded }=a+b\left(1-\exp ^{-c}\right)
$$

This model supposes 3 fractions in the forage: one rapidly degradable fraction $(a)$, one with slower degradation (b) at a rate reducing exponentially $\left(e^{-c}\right)$ and one non-degradable fraction $(100-a-b)$. Parameter values $a, b$ and $c$ of this model were obtained by fitting the data using a nonlinear regression procedure, based on Marquardt's method performed by the NLIN procedure of SAS (SAS Institute, 1985). By fixing particle turnover at $0.06 / \mathrm{h}$ (Vérité and Peyraud, 1989), forage degradability can be calculated by the following equation:

$$
\% \text { degrated } \mathrm{N}=a+b c /(c+0.06)
$$

The microbial contamination of bag residues can induce a important bias on the measurement of nitrogen degradability. To take into account this microbial contamination, we estimated the error $(E R)$ related to contamination from chemical composition of forages (MichaletDoreau and Ould-Bah, 1989), according to the formula:

$$
E R=6.4-0.035 C P+0.017 N D F
$$

The crude protein $(C P)$ and neutral detergent fiber (NDF) content of forages were expressed in $\mathrm{g}$ per $\mathrm{kg} \mathrm{DM}$.

\section{Statistical analysis}

The effect of stage of maturity on $\mathrm{N}$ degradation was tested for each forage by an analysis of vaiance using the SAS GLM procedure (SAS Institute, 1985) with 2 main effects: stage and animal. Vegetation stage differences were separat$\theta d$ by the Duncan's multiple range test when the effect was significant.

\section{RESULTS}

The chemical composition of the forages is given in table I. The crude protein content decreases with vegetation stage from 15.0 to $8.6 \%$ DM for rye grass and from 28.8 to $19.5 \%$ for lucerne. The cell wall constituents content increased with vegetation stage in both forages.

Data on in situ $\mathbf{N}$ degradability are given in table II. At a similar vegetation stage, $\mathbf{N}$ lucerne degradability was always higher than that of rye grass, and means were respectively 73.5 and $70.7 \%$. The higher degradability of luceme was essentially due to higher degradation rate of legumes (table II). For both forages, there was an effect of stage of maturity on forage $\mathrm{N}$ degradability. For grass, a high value occurred at the beginning of growth, $72.2 \%$ on average from leafy stage to heading, but this decreased quickly between heading and end of heading by $7.6 \%(1.1 \% / d)$. The rapidly degraded fraction increased as the forage became more mature, values ranged from a mean of $19.9 \%$ at the vegetative stage to $39.2 \%$ at the late stages. This variation was compensated by a decrease in degradation rate and an increase in undegradable fraction. After heading, only the degradation rate continued to decrease, and consequently the $\mathbf{N}$ degradability also decreased. For lucerne, the decrease of $\mathbf{N}$ degradability was approximately linear between the vegetative stage $(79.0 \%)$ and the end of budding $(70.0 \%)$, corresponding to a decrease of $0.3 \% / d$. This variation was related to a significant decrease in the rapidly degraded $\mathrm{N}$ fraction from 34.3 to $20.0 \%$ and of $\mathrm{N}$ 
Table I. Chemical composition of forages.

\begin{tabular}{lllrrrrr}
\hline Maturity stage & $\begin{array}{l}\text { Cutting date } \\
(1990)\end{array}$ & $D M(\%)$ & Ash & $C P$ & $\begin{array}{c}N D F \\
(g / \mathrm{kg} D M)\end{array}$ & ADF & $A D L$ \\
\hline Italian ray-grass & & & & & & & \\
$\quad$ Leafy stage & 7 March & 23.3 & 91 & 150 & 437 & 179 & 25 \\
Leafy stage & 13 March & 27.5 & 105 & 140 & 454 & 196 & 27 \\
Grazing stage & 18 April & 25.7 & 111 & 118 & 472 & 203 & 28 \\
Heading & 2 May & 30.0 & 118 & 104 & 469 & 219 & 35 \\
End of heading & 9 May & 33.6 & 119 & 86 & 524 & 274 & 51 \\
& & & & & & & \\
Lucerne & & & & & & & \\
Vegetative & 21 March & 19.7 & 105 & 288 & 365 & 204 & 54 \\
Vegetative & 2 April & 25.4 & 101 & 235 & 391 & 229 & 56 \\
Early budding & 9 April & 25.8 & 96 & 214 & 442 & 273 & 83 \\
Budding & 17 April & 26.3 & 96 & 204 & 442 & 273 & 76 \\
End of budding & 24 April & 28.2 & 89 & 195 & 462 & 284 & 95 \\
\hline
\end{tabular}

Table II. In situ $\mathrm{N}$ degradation of forages.

\begin{tabular}{lcccccc}
\hline Maturity stage & $\begin{array}{c}\text { Rapidly } \\
\text { degraded } \\
\text { fraction } \\
(\% N)\end{array}$ & $\begin{array}{c}\text { Slowly } \\
\text { degraded } \\
\text { fraction } \\
(\% N)\end{array}$ & $\begin{array}{c}\text { Undegraded } \\
\text { fraction } \\
(\% N)\end{array}$ & $\begin{array}{c}\text { Degradation } \\
\text { rate/h }\end{array}$ & $\begin{array}{c}\text { Uncorrected } \\
N \\
\text { degradability } \\
(\% N)\end{array}$ & $\begin{array}{c}\text { Corrected } \\
N \\
\text { degradability } \\
(\% N)\end{array}$ \\
\hline Italian ray-grass & & & & & & \\
Leafy stage & $20.6^{\mathrm{a}}$ & $74.8^{\mathrm{b}}$ & $4.7^{\mathrm{a}}$ & $0.142^{\mathrm{a}}$ & $72.9^{\mathrm{a}}$ & $81.4^{\mathrm{a}}$ \\
Leafy stage & $19.2^{\mathrm{a}}$ & $76.8^{\mathrm{a}}$ & $3.7^{\mathrm{a}}$ & $0.140^{\mathrm{a}}$ & $73.1^{\mathrm{ab}}$ & $82.3^{\mathrm{a}}$ \\
Grazing stage & $38.9^{\mathrm{b}}$ & $50.6^{\mathrm{b}}$ & $10.5^{\mathrm{b}}$ & $0.110^{\mathrm{b}}$ & $71.6^{\mathrm{b}}$ & $81.8^{\mathrm{a}}$ \\
Heading & $41.4^{\mathrm{b}}$ & $47.4^{\mathrm{b}}$ & $11.3^{\mathrm{b}}$ & $0.103^{\mathrm{b}}$ & $71.3^{\mathrm{b}}$ & $82.0^{\mathrm{a}}$ \\
End of heading & $37.4^{\mathrm{b}}$ & $50.7^{\mathrm{b}}$ & $11.8^{\mathrm{b}}$ & $0.070^{\mathrm{c}}$ & $64.6^{\mathrm{c}}$ & $76.9^{\mathrm{b}}$ \\
& & & & & & \\
Lucerne & & & & & & \\
Vegetative & $34.3^{\mathrm{a}}$ & $62.0^{\mathrm{a}}$ & $3.7^{\mathrm{a}}$ & $0.162^{\mathrm{a}}$ & $79.0^{\mathrm{a}}$ & $81.4^{\mathrm{a}}$ \\
Vegetative & $27.4^{\mathrm{b}}$ & $61.7^{\mathrm{a}}$ & $9.5^{\mathrm{b}}$ & $0.154^{\mathrm{a}}$ & $73.2^{\mathrm{b}}$ & $77.9^{\mathrm{bc}}$ \\
Early budding & $24.0^{\mathrm{b}}$ & $67.9^{\mathrm{b}}$ & $8.1^{\mathrm{bc}}$ & $0.152^{\mathrm{a}}$ & $72.7^{\mathrm{b}}$ & $79.0^{\mathrm{c}}$ \\
Budding & $18.4^{\mathrm{c}}$ & $74.0^{\mathrm{c}}$ & $7.4^{\mathrm{c}}$ & $0.166^{\mathrm{a}}$ & $72.8^{\mathrm{b}}$ & $79.5^{\mathrm{c}}$ \\
End of budding & $20.0^{\mathrm{c}}$ & $71.9^{\mathrm{c}}$ & $8.1^{\mathrm{bc}}$ & $0.137^{\mathrm{b}}$ & $70.0^{\mathrm{c}}$ & $77.4^{\mathrm{b}}$ \\
\hline
\end{tabular}

For each forage, different subscripts in a same column correspond to a significant difference $(P<0.05)$. 
degradation rate which varied from 0.162 to $0.137 \mathrm{~h}^{-1}$.

If the $\mathrm{N}$ degradability values were corrected to take into account microbial contamination, $\mathrm{N}$ degradability increased on average by $10.2 \%$ for grasses and by $5.5 \%$ for lucerne, and $\mathrm{N}$ degradability was then $80.9 \%$ and $79.0 \%$ respectively. However, this increase was not the same for all the stages of maturity. The decrease in $\mathrm{N}$ degradability with the stage of forage maturity was lower than for the uncorrected values, $5 \%$ between heading and end of heading against $7.6 \%$ for grass, and $4 \%$ against $9 \%$ for lucerne when the microbial contamination was taken into account.

\section{DISCUSSION}

In this trial, the mean degradability of rye grass nitrogen was $70.7 \%$, near to the value $(76.8 \%)$ calculated from the data of Van Vuuren et al (1990) obtained for rye grass cut at different stages of maturity. In contrast, Le Goffe (1991) reported a higher value (81.7) for a large number of fresh forage the samples (72). The differing reports can be related both to the chemical composition of the samples and to their preparation. The CP content of the grasses varied between $120 \mathrm{~g}$ in this study and $189 \mathrm{~g} /$ $\mathrm{kg} / \mathrm{DM}$ in Le Goffe's study, whereas in the Dutch study (Van Vuuren et al, 1990) mean $C P$ was $250 \mathrm{~g} / \mathrm{kg}$ DM. Moreover, sample preparation prior to in situ incubation was $60^{\circ} \mathrm{C}$ oven-drying and grinding over $0.8 \mathrm{~mm}$ in this study, freeze-drying and grinding (Le Goffe, 1991) or chopping and freezing (Van Vuuren et al, 1990). Compared with the fresh initial forage, over-drying involves a decrease in nitrogen degradability when the sample is chopped and has no effect when this is ground after drying. Freeze-drying followed grinding leads to an overestimation of $\mathrm{N}$ degradability compared with the fresh initial forage
(Michalet-Doreau, 1989; Vanhatalo and Varvikko, 1989). The nitrogen degradability of forages could have been overestimated in the Le Goffe's study. Lindberg (1988) also measured $\mathbf{N}$ degradation kinetics for a timothy harvested at different stages of maturity and dried at $65^{\circ} \mathrm{C}$. The mean $\mathrm{N}$ degradability calculated from degradation parameters was $60.9 \%$, a much lower value than those reported from the other trials. However, when Lindberg (1988) took into account microbial contamination of bags in the rumen, the $\mathrm{N}$ degradability increased to a mean of $85.1 \%$. In the present study, the degradability of rye grass $\mathrm{N}$ also increased from 70.7 to $80.9 \%$ if microbial contamination was taken into account. In an earlier trial on 6 grass samples harvested at different stages of maturity, the mean $\mathrm{N}$ degradability of the fresh forages was $75.9 \%$ (Michalet-Doreau and Ould-Bah, 1992).

On average, the lucerne $N$ degradability was higher $(80.9 \%)$ than that of rye-grass $(70.7 \%)$, this difference being due to a higher degradation rate of lucerne. Osibe et al (1987) found a greater difference between legumes $(60.9 \%)$ and grass $(50.0 \%)$. When microbial contamination was taken into account, the lucerne $\mathrm{N}$ degradability was approximately equal to that of grass, 80.9 and $79.0 \%$ respectively.

The $\mathbf{N}$ degradability decreased with advancing age by $7.6 \%$ for rye grass and by $9 \%$ for lucerne during the experimental period. This decrease was linear for the lucerne, but the grass $\mathrm{N}$ degradability showed a plateau followed a sudden decrease after the heading. This difference in behaviour between grasses and lucerne according to maturity stage is also found for the other nutritive characteristics, such as digestibility (Demarquilly and Jarrige, 1971). Lindberg (1988) and Van Vuuren et al (1990) followed the $N$ degradability of grasses over a number of weeks. The $\mathbf{N}$ degradability values were higher in early 
cut than in late cut grass batches, and the $\mathrm{N}$ degradability described a curve with a plateau over a 6-wk period followed by a large decrease at the end of growth in the study of Van Vuuren et al (1990). In this study, the $\mathrm{N}$ degradability decrease was related to the decrease of the $\mathrm{N}$ soluble fraction, whereas in our study the $\mathrm{N}$ degradability decrease was accompanied by an increase in the $\mathrm{N}$ rapidly degraded fraction. But the measurement method of this fraction was not similar in the 2 studies, and this could be at the origin of the difference. In the study of Van Vuuren (1990), the soluble fraction was estimated as the fraction disappearing from the bags during washing (zero incubation time) and then was independent of the degradation curve. In contrast, in our study, the rapidly degraded fraction was estimated by adjustment to an exponential model. The value was dependent on the degradation curve, and when the degradation rate decreased, the rapidly degraded fraction increased. In these 2 studies, microbial contamination was not taken into account and this could introduce a bias into the results. When microbial contamination was taken into account, the decrease of $\mathrm{N}$ degradability with advancing age was lower, ie $5 \%$ for nye grass and $4 \%$ for lucerne in this experiment, and even $0 \%$ for Lindberg (1988). Messman et al (1992) studied the $\mathrm{N}$ disappearance of 2 bromegrass hays harvested at the late-boot or full-head stage of maturity. Advanced maturity decreased the degradability of microbial-corrected $\mathrm{N}$ by $5 \%$. The variations in $\mathrm{N}$ degradability of rye grass studied by Le Goffe (1991) were similar, from 96 to $91 \%$ during the first cycle of vegetation. However the extent of the decrease can vary. In a earlier study, the degradability of microbial-corrected $N$ of forages harvested at 2 stages of maturity decreased by $16.8 \%$ with a rye grass and only by $5.1 \%$ with the 3 other forages (Michalet-Doreau, 1990).
The results of this study suggest that stage of maturity of forage has an effect on the $\mathrm{N}$ degradability in the rumen, but this effect of maturation on the protein value of Italian rye grass is different from that of lucerne. In rye grass, ruminal protein degradability stays constant for some weeks, especially when it is corrected for microbial contamination, and then suddenly falls, whereas in lucerne ruminal protein degradability decreases linearly.

\section{REFERENCES}

Cerneau P, Michalet-Doreau B (1991) In situ starch degradation of different feeds in the rumen. Reprod Nutr Dev 31, 65-72

Demarquilly C, Jarrige R (1971) The digestibility and intake of forages from artificial and natural grassland. In: Proc 4th Eur Meeting Forages. Lausanne, 91-106

Demarquilly C, Andrieu J, Michalet-Doreau B, Sauvant $D$ (1989) Measurement of the nutritive value of feeds. In: Ruminant Nutrition: Recommended Allowances and Feed Tables (Jarrige R, ed) INRA, Paris, 193-204

Goering MK, Van Soest PJ (1970) Forage Fiber Analysis. Agric Handbook No 379, Agric Res Ser, USDA, Washington, DC, pp 20

Le Goffe P (1988) Evolution de la dégradabilité de l'azote des fourrages verts au cours du premier cycle de végétation. Reprod Nutr Dév 28, 165-166

Le Goffe P (1991) Méthodes d'études et facteurs de variation de la dégradabilité de l'azote des fourrages verts dans le rumen. Thesis, ENSA de Rennes, pp 82

Lindberg JE (1985) Influence of rumen degradability with in sacco technique and various in vitro methods: a review. Acta Agric Scand (suppl) 25, 64-97

Lindberg JE (1988) Influence of rumen time and $\mathrm{N}$ fertilization on the nutritive value of timothy. Swedish J Agric Res 18, 85-89

Madsen J, Hvelplund T (1985) Protein degradation in the rumen. A comparison between in vivo, nylon bag and buffer measurements. Acta Agric Scand (suppl) 25, 103-124 
Mehrez AZ, Orskov ER (1977) A study of the artifical fibre bag technique for determining the digestibility of feeds in the rumen. J Agric Sci (Camb) 88, 645-575

Messman MA, Weiss WP, Erickson DO (1992) Effects of nitrogen fertilization and maturity of bromegrass on nitrogen and amino acid utilization by cows. J Anim Sci 70, 566-575

Michalet-Doreau B (1990) Variation of in sacco nitrogen degradability of green forages in rumen. In: Proc 41st Annual Meeting Eur Assoc Anim Prod. 228-229

Michalet-Doreau B, Ould-Bah MY (1989) Estimation of the extent of bacterial contamination in bag residues and its influence on in sacco measurements of forage nitrogen degradation in rumen. In: Proc 16th Int GrassI Congress. Nice, France 909-910

Michalet-Doreau B (1989) Use of in sacco method to predict the feeding value of forage. In: Proc 16th Int Grassi Congress. Nice, France, 1850-1852

Michalet-Doreau B, Ould-Bah MY (1992) Influence of hay-making on in situ nitrogen degradability of forage in cows. J Dairy Sci 75, 782-788

Nocek JE (1988) In situ and other methods to estimate ruminal protein and energy digestibility A review. J Dairy Sci 71, 2051-2069

Orskov ER, McDonald I (1979) The estimation of protein degradability in the rumen from incubation measurements weighed according to rate of passage. J Agric Sci (Camb) 92, 499-503
Osibe A, Ogawa M, Masubuchi T (1987) The degradability of crude forage protein in the rumen of sheep. A comparison of leguminous and gramineous crude protein degradability. Bull Natt Grass/ Aes Inst 37, 58-63

SAS Institute (1985) SAS User's Guide: Statistics, Version 5 Edition. SAS Inst Inc, Cary, NC

Tamminga S, Van Vuuren AM, Van der Koelen CJ, Ketelaar RS, Van der Togt PL (1990) Ruminal behaviour of structural carbohydrates, non-structural carbohydrates and crude protein from concentrate ingredients in dairy cows. Neth J Agric Sci 38, 513-526

Vanhatalo A, Varvikko T (1989) Influence of sample preparation on the ruminal nylon bag degradation values of grass silage. Am J Agric Sci 2, 413-415

Van Eys JE, Reid RL (1987) Ruminal solubility of nitrogen and minerals from fescue and fescue-red clover herbage. J Anim Sci 65, 1101-1112

Van Vuuren AM, Tamminga S, Ketelaar RS (1990) Ruminal availability of nitrogen and carbohydrates from fesh and preserved herbage in dairy cows. Neth J Agric Sci 38, 499-513

Vérité R, Peyraud JL (1989) Protein: the PDI system. In: Ruminant Nutrition: Recommended Allowances and Feed Tables (Jarrige R, ed) INRA, Paris, 33-46

Vik-Mo $L$ (1989) Degradability of forages in sacco. 2. Silages of grasses and red clover at two cutting times, with formic acid and without additives. Acta Agric Scand 39, 53-64 